\title{
The regional allocation of infrastructure investment: the role of equity, efficiency and political factors
}

\author{
Antoni Castells and Albert Solé-Ollé* \\ Universitat de Barcelona and Barcelona Institute of Economics (IEB)
}

The paper analyses the main determinants of the regional allocation of infrastructure investment.The estimated investment equation is derived from a general specification of the government's objective function (Berhman and Craig, AER, 1987), which accounts both for the equity-efficiency trade-off and for deviations from this rule arising from political factors. The reaction of investment to changes in the regional output tells us about the strength of the equity-efficiency trade-off. The main political factor considered is the incumbent's marginal probability of gaining/loosing a regional representative in the national legislature. The equation is estimated with a panel of data on investment and capital stock of transportation infrastructure (i.e., roads, rails, ports and airports) for the Spanish departments (NUTS3) during the period 1987-96. We use a dynamic specification of the equation that allows for slow adjustment and which is estimated by GMM methods (Arellano and Bond, 1991).The results suggest that efficiency criteria play only a limited role in the geographical distribution of goverment's infrastructure investment. Regional specific infrastructure needs and political factors appear also as factors explaining the regional allocation of infrastructure investment.

Keywords: infrastructutures, growth, political economy

JEL codes: $\mathrm{R} 1, \mathrm{O} 4$

*Corresponding address: Facultat de Ciències Econòmiques

(Universitat de Barcelona)

Avda. Diagonal, 690, Torre $4^{\mathrm{a}}$, Planta $2^{\mathrm{a}}$

Phone/Fax:0034-934035919, 0034-934021812

e-mail: asole@eco.ub.es

We acknowledge helpful comments by Daniel Montolio and Elisabet Viladecans and excellent research assistance by $\mathrm{M}^{\mathrm{a}}$ Carmen Arenols. This paper has benefited from the financial support of CICYT SEC-2000-08786, the Project and 99-SGR-17 (Generalitat de Catalunya) and IEF (Instituto de Estudios Fiscales, Ministry of Economics). 


\section{Introduction}

In most countries, the central government has considerable policy discretion in the allocation of infrastructure investment across regions. For example, it is by far easier to reallocate road funds from one region to another than to perform this redistribution by means of public employment or consumption. Redistribution of infrastructure investments from one region to another can not be considered as random: they obey both to economic and political motivations. The purpose of this paper is to analyze these motivations, asking questions like: is infrastructure investment directed to the regions with higher project's impact, following thus an efficiency criterion?; or, otherwise, is redistribution the main criterion guiding the regional allocation of infrastructure investment, being funds devoted to regions with low output levels? Of course, there is also the possibility that none of these objectives coincide with government's purposes, and that these are based on pure political interest. Following this intuition, we may therefore ask: which are these political drivers and which is its influence on observed infrastructure investment allocations?

We try to answer these questions by estimating an equation that picks up the main determinants of the allocation of infrastructure investment among the Spanish regions. The estimated investment equation is theoretically derived from a very general specification of central's government objective function, which accounts both for the equity-efficiency trade-off and for deviations from this rule arising from political factors. The equation is estimated with a panel of data on investment and capital stock of transportation infrastructure (i.e., roads, railroads, ports and airports) for the Spanish departments (NUTS3) during the period 1987-96. We selected transportation infrastructures for two reasons. First, they are the most relevant infrastructure category in Spain, accounting for nearly $70 \%$ of total productive infrastructure investment (Ministerio de Fomento, 2001). Second, these are the infrastructures that show a major impact on output in production function analyses with Spanish data (see, e.g., Mas et al., 1996) ${ }^{1}$. Casual observation also shows that most demands of infrastructure improvements by regional business groups focus on transportation projects. We feel that evidence on the

\footnotetext{
${ }^{1}$ Other sizeable productive infrastructure categories, as water projects and urban infrastructures (nearly 25\%; Ministerio de Fomento, 2001) do not show any effect on output in empirical analyses. Also we do not consider the effect of investments in the so-called social infrastructures (e.g., health, education and so on) first because they use not to be included among productive infrastructures, but also mainly because investment in these categories is less easily diverted from one region to the other and, actually, investments in these categories are the full responsibility of regional governments.
} 
Spanish experience will be of interest across Europe, also for various reasons. First, up to our knowledge this is one of the first papers analysing this topic with data corresponding to an European country. The paper by Cadot et al. (1999), performing a similar analysis in the case of the French regions, is the main exception to this rule. Second, as part of infrastructure projects in Spain are financed by European funds, it is of wide European interest to know which are the criteria explaining the regional allocation of infrastructure investment.

The paper is related to the literature analyzing the determinants of public investment. Among these papers we could cite the works of Holtz-Eakin and Rosen $(1989,1993)$ and Petchey et al. (2000). But both papers focus on investment spending decisions made by subnational governments. Papers analyzing central government's expenditure allocation across jurisdictions are less common. Among these papers we should include some works that try to quantify the efficiency-equity trade-off implicit in the territorial distribution of public services (see, e.g., Behrman and Craig, 1987, and Craig and Heikkila, 1989), or other recent papers that focus on political motivations driving the territorial distribution of intergovernmental grants and other public programs (e.g., Levitt and Snyder, 1995, Cadot et al., 1999, Case, 2001, Dahlberg and Johansson, 1999 and Johansson, 2001). However, as we told before, only the paper by Cadot et al. (1999) is specifically centered on infrastructure investment allocation. In the Spanish case, some empirical papers have previously analyzed the rules implicit in the territorial distribution of public investment (De la Fuente, 1999 and 2001, and Bosch and Espasa, 1999) ${ }^{2}$. These papers do not account for the role of political factors, which have been previously considered by Boix (1995) and De la Fuente and Vives (1995) ${ }^{3}$. The main difference between this literature and our work is that the investment allocation equation we use is theoretically derived. This specification allows us to take into account the equityefficiency trade-off accounting at the same time for political influences.

In our case, and with the only purpose of guiding the specification of the equation explaining the territorial distribution of infrastructure investment, we model the behavior of the government as having a well-defined objective function with output levels of all regions

\footnotetext{
${ }^{2}$ There are also some papers analyzing the expenditure made by Spanish regional governments. See e.g., Castells and Solé (2000) for an analysis of spending in different infrastructure categories, and Lago (2001) for a paper focusing on total regional investment.

${ }^{3}$ The first author reach the conclusion that they were quite important during the eighties but the other paper (focusing specifically on infrastructure allocation) conclude that they are not relevant.
} 
appearing as arguments. Our approach can be considered an extension of Behrman and Craig (1987) to the case of productive public investment. Another difference with this paper is the inclusion of political factors in the equation. As we said before, our work shares also some similarities with the paper of Cadot et al. (1999) analyzing the regional distribution of infrastructure spending in France. However, these authors focus on lobbying efforts by business groups as the main channel of political influence of the different regions, while we center mainly on electoral considerations (e.g., central government incumbent's marginal probability of gaining/loosing a departmental representative in the national legislature).

The paper is also related to the vast literature on the effects of infrastructures on output arising from Aschauer's seminal papers (1989a and 1989b). First, although this is not our purpose here, the results showing that investment allocation responds to changes in the regional economies suggest that politicians act "as if" infrastructures have economic effects. Moreover, as our equation is derived from a model explicitly including a production function, the estimates may indeed be interpreted as an indirect test on the effect of infrastructures. We believe that our approach, which consists on looking at the determinants of investment instead than at the effects of infrastructures on the economy, we will get a new perspective on this topic. Second, our results suggest that infrastructure growth depends on output growth and other exogenous variables (e.g., political factors). This ultimately means that infrastructure capital should be considered as endogenous in production function estimation. Our results will help in the selection of instruments to be used in these studies.

The paper is organized as follows. In the second section we introduce a simple model of infrastructure allocation across regions. This model allows us to obtain an infrastructure allocation equation. In the third section we introduce some modifications that need to be introduced before estimating the investment equation; the data base and econometric procedures are also discussed in this section. The results are presented in the fourth section. Finally, the last section concludes with an outline of possible utilities of the results and a brief discussion of some economic policy implications.

\section{A model of infrastructure allocation across regions}

The equation explaining the allocation of investment in transportation infrastructure across regions is obtained from the development of a stylized model combining two different blocks: 
(i) a production function relating infrastructure capital stock to regional output, and (ii) a social choice rule that states that investment in a region depends on its output per head. The production function is the link that relates infrastructure investment in each region to regional output. We begin with the production block, introducing in a second stage the objective function. As the empirical analysis deals with transportation infrastructure, the discussion from now on will explicitly refer to the output effects of this type of infrastructure.

\section{(i) Production function}

Following Fernald (1999), we suppose that, for each region $i$ and year $t$, output depends on inputs such as non-transportation private capital $K_{i t}$, labor $L_{i t}$, and transport services that are produced within the region, $T_{i t}$. Output also depends on the Hicks-neutral level of technology, $P_{i t}$. Transport services depend upon the flow of services provided by the government's transportation infrastructure $\left(Z_{i t}\right)$ and by a transportation input internal to regional firms as, for example, the stock of industrial vehicles $\left(X_{i t}\right)^{4}$. Hence, the regional production function takes the form:

$$
Y_{i t}=P_{i t} \cdot F\left(K_{i t}, L_{i t}, T\left(X_{i t}, Z_{i t}\right)\right)
$$

Most papers analysing the growth effects of infrastructures implicity assume that services provided by public capital are non-rival. Only recently some papers appeared extending the basic model to include congestion effects, both theoretically (Fisher and Turnovsky, 2000, and Glomm and Ravikumar, 2000) and empirically (Fernald, 1999, and Boarnet, 2001). We take also into account that transportation infrastructures may be congested and, therefore, that the services provided by the infrastructure stock $\left(Z_{i t}\right)$ depend on the size of that stock $\left(C_{i t}\right)$ but also on the level of utilization $\left(U_{i t}\right)^{5}$. We assume for the moment a very flexible relationship among these three variables, $Z_{i t}=Z\left(C_{i}, U_{i t}\right)$, imposing only that $Z_{c}>0$ y $Z_{u}<0^{6}$.

\footnotetext{
${ }^{4}$ From now on we will make reference to this input as vehicles, although its definition is somewhat more general. We must note that Fernald's (1999) model was applied exclusively to roads. Therefore, connecting vehicles to roads was straightforward in that case. We feel, however, that the connection of vehicles and other transportation infrastructures (e.g., railroads, ports and airports) is equally plausible, given that inter-modality is a common feature of nowadays transportation of both people and goods.

${ }^{5}$ In the case of roads, utilization can be measured by number of $\mathrm{km}$ driven. In the case of railroads, ports and airports by number of passengers and tons of goods transported.

${ }^{6}$ The most common functional form used to account for congestion is one that assumes a constant elasticity, like: $Z_{i t}=C_{i l} / U_{i t}{ }^{\alpha}$, where $\alpha=1$ in the case of a private good and $\alpha=0$ in the case of a pure public (non-congested) good. This functional form has been used by Fernald (1999) in his analysis of road effects on productivity. However, it has been criticized on the grounds of exhibiting decreasing
} 
Suppose now that firms are perfectly competitive and have constant returns to scale to private factors, which can be instantaneously adjusted. Let $F_{J}$ represent the derivative of the production function $F$ with respect to input $J$. Cost minimization implies that the elasticity of output with respect to $J, F_{J} J / F$, equals input's share in revenue, $S_{J}$. By assumption, there are no economic profits, so the shares to private inputs sum to one. Given these assumptions and the specification of $Z_{i t}$, the effect on output of an increase in transportation infrastructure stock can be expressed as:

$$
F_{c}=F_{z} \cdot Z_{c}=\left(\frac{F_{z} \cdot Z_{i t}}{F_{x} \cdot X_{i t}}\right) \cdot\left(\frac{F_{x} \cdot X_{i t}}{F_{i t}}\right) \cdot\left(\frac{Z_{c} \cdot C_{i t}}{Z_{i t}}\right) \cdot \frac{F_{i t}}{C_{i t}}=\omega_{i t} \cdot S_{i t}^{x} \cdot E_{i t}^{c} \cdot \frac{F_{i t}}{C_{i t}}
$$

where $F_{c}=\partial F / \partial C, F_{z}=\partial F / \partial Z$ and $Z_{c}=\partial Z / \partial C$. The four elements that appear in $F_{c}$ are: (i) the ratio between the elasticity of output with respect to government's transportation services and the elasticity of output with respect to vehicles $\left(\omega_{i t}\right)$, (ii) the share of vehicles in output $\left(S_{i t}{ }^{x}\right)$, (iii) the elasticity of infrastructure services to changes in the infrastructure stock $\left(E_{i t}{ }^{c}\right)$, and (iv) the ratio of $F_{i t}$ to $C_{i t}$. We expect $\omega_{i t}$ to be positive, which captures the notion that sectors relatively vehicle-intensive are also intensive in the use of government's transportation infrastructure. Further assumptions about technology help to simplify this expression and aid in interpreting the results. Suppose that $T_{i t}$ is separable from $K_{i t}$ and $L_{i t}$, as is implicitly assumed in (1), and is produced with the same Cobb-Douglas technology in all the regions, so $\omega_{i t}=\omega$. Now expression (2) can be simplified as:

$$
F_{c}=\omega \cdot S_{i t}^{x} \cdot E_{i t}^{c} \cdot \frac{F_{i t}}{C_{i t}}
$$

Expression (3) states that the marginal effect of transportation infrastructure differs from region to region. The effect is higher the lower the ratio of infrastructure stock to production. But this effect is also higher the higher is share of vehicles in output, meaning that infrastructure needs may depend also on the industrial mix of the region. It is also higher the higher the elasticity of infrastructure services to the stock. As we will argue below, it is quite possible for $E_{i t}{ }^{c}$ to increase with utilization, meaning that the marginal effect of infrastructures is higher where there is more congestion. The central government will take into account all those effects when deciding about the regional distribution of transportation infrastructure. 


\section{(ii) Social choice rule}

We assume that transportation infrastructure investment is distributed among regions "as if" there is a constrained maximization of a central government social welfare function, defined over the distribution of output among the regions of the country. Following the approach of Behrman y Craig (1987), we use a CES social welfare function that allows varying degrees of relative regional inequality aversion and, at the same time, unequal treatment of regions with the same output levels ${ }^{7}$. This social welfare function can be expressed as:

$$
W_{t}=\left(\sum_{i} N_{i t} \cdot \Psi_{i t} \cdot\left(Y_{i t} / N_{i t}\right)^{\phi}\right)^{1 / \phi}
$$

where $N_{i t}$ and $Y_{i t} / N_{i t}$ are population and output per head of region $i$ in year $t$. The $\phi$ parameter quantifies the aversion to regional output inequality, and its variation range goes from $-\infty$ to one. As $\phi$ becomes more negative, inequality aversion increases. When $\phi \rightarrow-\infty$ the function approaches the pure equity concerns case. In the intermediate Cobb-Douglas case $\phi$ is zero. And if $\phi$ is equal to one, then the government is exclusively worried about efficiency. In this case, $W$ equals national output $(W=Y)$. The estimation of the $\phi$ parameter is one of the main purposes of the paper, since its value will tell us about the relative weight assigned to efficiency and redistribution in investment allocation.

The parameters $\Psi_{i t}$ differ form region to region and relate to equal vs. unequal concern. If there is equal concern, $\Psi_{i t}=\Psi_{t}$ for all regions. If there is unequal concern, $\Psi_{i t}$ depends on region's specific characteristics. Those parameters are, therefore, an indicator of the deviation of the central government investment from an investment allocation rule strictly based on the equity-efficiency trade-off implicit in the $\phi$ parameter. In our context the most straightforward interpretation of the $\Psi_{i t}$ parameters is to consider that they pick up political considerations that make a region attractive enough to the government to justify a deviation from the equityefficiency rule. As we will see in the empirical section, electoral considerations (e.g., risk of losing political representatives) play an important role in the distribution of transportation investment across regions ${ }^{8}$.

\footnotetext{
${ }^{7}$ See Behrman and Craig (1987) and Craig and Heikkila (1989) for empirical studies applying this methodology to the distribution of police inputs among city districts, and Behrman and Sah (1984) for a paper applying it to the distribution of international aid across developing countries.

${ }^{8}$ It must be noted that Behrman and Craig (1987) use economic and demographic variables in order to account for $\Psi_{\text {it. }}$. Although these may also be included in our analysis we feel that they will ultimately
} 
The main advantage of this approach to the social decision rule applied to the distribution of public investment across regions is its relative simplicity, allowing to obtain a solution easy to implement at the empirical level, while simultaneously accounting for the equity-efficiency trade-off (quantified by $\phi$ ) and the deviation from it (quantified by $\Psi_{i t}$ ). As we will show below, with this approach we will obtain an equation explaining the determinants of government's investment in different regions that is additive in output and political factors. This fact makes possible the decompose investment variance in the share due to the equityefficiency trade-off and the share due to political calculus. One drawback may be that the approach does not provide an structural model of government behavior. However, we have to note that recent theoretical articles in the political economy field end up with very similar specifications, where output and political factors are additively combined ${ }^{9}$.

\section{(iii) Optimal infrastructure stock}

The problem of the central government consists of choosing a regional distribution of transportation investment to maximize the function (4), taking into account the effect of transportation infrastructure capital on output (3), and an exogenous budget constraint like:

$$
\sum_{i} I_{i t} \leq R_{t}
$$

where $I_{i t}$ is investment in region $i$ and year $t$ and $R_{t}$ are resources available to invest in transportation infrastructure in a given year $t$. We take $R_{t}$ as given and constant across regions. The first assumption is consistent with investment budgeting practices in Spain, since the overall level of investment for a given year is determined before its distribution by categories and regions ${ }^{10}$. This first assumption is also consistent with our empirical purpose, since we will analyze the empirical factors that drive the regional distribution of investment, controlling for total investment effort done in a given year. Thus, we do not aim to explain why the total amount of investment made by the government changes from year to year. The second assumption, constancy of available resources across regions, picks up the fact that the

account for the political cloud of the region. It is less clear that they will pick up differences in needs, since this factor has been already accounted for by the specific form of the production function.

${ }^{9}$ See, for example, the work of Dixit and Londregan (1998), that model politicians as having partisan preferences with respect to the efficiency-equity trade-off but that also care about reelection.

${ }^{10}$ This amount is determined each year depending on the availability of resources and the need for fiscal consolidation. All planned investment projects are then ranked by a budgetary committee, and the amount of resources available for investment determines the number of these projects to be undertook next year. 
central government is dividing a common pie among the different regions. However, this procedure does not account for the fact that some funds are earmarked to specific regions. Concretely, some regions are entitled to a minimum investment level that comes from the European Funds (e.g., ERDF, Cohesion Fund) and from Spanish regional policy. To control for this fact we could have included this minimum amount as an additional constraint. The problem is, however, that we are not able to measure it at the geographical level we employ in the analysis. If the restriction is not binding (i.e., the level of investment in the region ends up being higher than the minimum) the omission will be irrelevant. However, nothing guarantees that this would happen in practice. As we will explain more in detail in the empirical section we will try to control for this including as explanatory variables an interaction of the set of time effects with a dummy that identifies the regions that are entitled to these funds.

Differentiating (4) subject to (3) and (5) with respect to transportation investment in a given region and year, we obtain the following first order condition:

$$
\frac{\partial W_{t}}{\partial\left(Y_{i t} / N_{i t}\right)} \cdot \frac{\partial\left(Y_{i t} / N_{i t}\right)}{\partial C_{i t}} \cdot \frac{\partial C_{i t}}{\partial I_{i t}}-\lambda_{t}=0
$$

where $\lambda_{t}$ is the marginal cost of public revenues, that we allow to change from year to year. The different terms of expression (6) can be obtained by differentiation of (4) and (3), taking into account (5) and $\partial C_{i t} / \partial \mathrm{I}_{i t}=1^{11}$. Substituting these expressions again into (6) and taking $\operatorname{logs}$, we are able to obtain the following expression for the optimal stock of infrastructures for each region $\left(\ln C_{i t}{ }^{*}\right)$ :

$$
\ln C_{i t}^{*}=B_{i t}+\phi \cdot \ln Y_{i t}+(1-\phi) \cdot \ln N_{i t}+\ln S_{i t}^{x}+\ln E_{i t}^{c}+\ln \Psi_{i t}
$$

where $B_{i t}=\ln P_{i t}+\ln \omega+(1-\phi) / \phi \cdot \ln W_{t}-\lambda_{t}$. Expression (7) can be interpreted as follows. The capital stock that the government plans for a region depends on the efficiency-equity tradeoff, implicit in the linear combination of output and population. Note than in the pure efficiency case (i.e., when $\phi=1$ ), population disappears from the equation and the coefficient of output is equal to one. If the social welfare function is Cobb-Douglas, then $\phi=0$ and only population (with a coefficient of one) appears in the equation. As $\phi$ becomes more negative, output appears in the equation with a negative coefficient and population with a positive

\footnotetext{
${ }^{11}$ This result derives directly from the permanent inventory equation that relates capital stock and investment: $C_{i t}=(1-\delta) \cdot C_{i t-1}+I_{i t}$, where $\delta$ is the annual depreciation rate of capital.
} 
coefficient that is higher than one. Note that for the government to have equity concerns, $\phi$ need not be negative; it suffices if $\phi$ is lower than one.

Therefore, equation (7) provides a simple way to test the for the strength of efficiency and equity in the regional distribution of investment. Moreover, note that this test is conditional to the inclusion in the equation of different kinds of controls. First, it includes variables accounting for different regional infrastructure needs, picked up by the vehicle output-share $\left(S_{i t}^{x}\right)$ and variables related to infrastructure congestion $\left(\ln E_{i t}^{c}\right)$. Second, it also includes variables related to the political cloud of the region $\left(\ln \Psi_{i t}\right)$. Therefore, we can conclude that equation (7) provides a characterization of the factors leading regional investment allocation: efficiency-equity trade-off, infrastructure needs and political factors.

\section{Empirical implementation}

\subsection{Some methodological aspects}

Some further aspects should be taken into account to ensure that equation (7) is implementable: (i) inclusion of individual and time effects, (ii) dynamics of investment decisions, and (iii) multiple levels of government investing in transportation infrastructures at the same time.

\section{(i) Individual and time effects}

Some measurement problems recommend to include both individual and time effects in the investment equation (7). First, it is difficult to quantify the $B_{i t}$ term. Observe from (7) that this term includes some factors that are invariant across regions (i.e., $\ln W_{t}$ and $\lambda_{t}$ ) and that can be controlled through the inclusion of time effects $\left(f_{t}\right)$. However, $B_{i t}$ also includes the term $\ln P_{i t}$, that picks up all those aspects that influence technology. The use of a panel of data also allows to control these influences through the inclusion of time $\left(f_{t}\right)$ and regional effects $\left(f_{i}\right)$.

Second, the model is not able to fully capture the overall institutional complexity involved in providing and financing infrastructure investment. For example, in Spain some regional governments have more transportation investment responsibilities than others. As the division of responsibilities in this area has not changed during the period analyzed, we can control for this fact by including regional effects in the equation. Another example are earmarked investment funds since, as we explain before, its quantification has enormous difficulties. By including regional effects we control for the fact that some regions receive these funds while 
others do not, a trait that is constant through the period. By including time effects we control by the fact that the total amount of funds received has changed over time. However, these funding increases only benefit the recipient regions. Because of this we include also an interaction between the time effects and a dummy equal to one for a recipient region $\left(\eta_{i}\right)$. Therefore, $B_{i t}$ can be expressed as $B_{i t}=f_{i}+f_{t}+\eta_{i} \times f_{t}+\varepsilon_{i t}$, being $\varepsilon_{i t}$ an uncorrelated error term with zero mean and constant variance.

\section{(ii) Dynamics}

With the aim to give more realism to the representation of the investment decision-making process, we may consider that it would be difficult for the government to instantaneously adapt the allocation of investment to a region after a change in its characteristics. A rigorous treatment of this question would have required to model investment decisions in an intertemporal framework, as in Holtz-Eakin and Rosen (1989 and 1993). However, as our purpose is related basically to the empirical implementation of equation (7), we will use a more practical approach, consisting of using a partial adjustment model. We assume that the infrastructure stock in a region will be the last period stock (i.e., $\left.\ln C_{i t-1}\right)$ plus a portion $(\rho)$ of the difference between that stock and the planned infrastructure stock $\left(\ln C_{i t}{ }^{*}\right)$. That is:

$$
\ln C_{i t}=\ln C_{i t-1}+\rho \cdot\left(\ln C_{i t}^{*}-\ln C_{i t-1}\right)
$$

Substituting (8) in (7) and using the regional and time effects representation of $B_{i t}$ we obtain the following expression:

$$
\begin{aligned}
\ln C_{i t}= & (1-\rho) \cdot \ln C_{i t-1}+\rho \cdot \phi \cdot \ln Y_{i t}+\rho \cdot(1-\phi) \cdot \ln N_{i t} \\
& +\rho \cdot \ln S_{i t}^{x}+\rho \cdot \ln E_{i t}^{c}+\rho \cdot \ln \Psi_{i t}+f_{i}+f_{t}+\eta_{i} \cdot f_{t}+\varepsilon_{i t}
\end{aligned}
$$

The estimation a dynamic panel equation like this poses some econometric problems. All the transformations commonly used to eliminate regional effects introduce correlation between the lagged endogenous variable and the error term, biasing OLS estimators if the time dimension of the panel is not large (Nickel, 1981, Arellano and Bond, 1991). A possible solution to this problem consists of taking first differences in (9) and then estimate the resulting equation by instrumental variables or GMM (Anderson and Hsiao, 1981; HoltzEakin, Newey and Rosen, 1988, and Arellano and Bond, 1991). We will explain more in detail the econo-metric procedure latter; for the moment it suffices to note that it will require the estimation of the model in first differences. Therefore, expression (9) becomes: 


$$
\begin{aligned}
\Delta \ln C_{i t} & =(1-\rho) \cdot \Delta \ln C_{i t-1}+\rho \cdot \phi \cdot \Delta \ln Y_{i t}+\rho \cdot(1-\phi) \cdot \Delta \ln N_{i t} \\
& +\rho \cdot \Delta \ln S_{i t}^{x}+\rho \cdot \Delta \ln E_{i t}^{c}+\rho \cdot \Delta \ln \Psi_{i t}+f_{t}+\eta_{i} \cdot f_{t}+\varepsilon_{i t}
\end{aligned}
$$

\section{(iii) Multiple levels of government}

Equation (10) aims to explain the change in the transportation infrastructure stock of the central government allocated to different regions. However, unfortunately, available data for the central government refers to investment instead of capital stocks ${ }^{12}$. But, as expressions (9) and (10) suggest it would not be appropriate to analyze investment behavior without considering the previous level of capital stock. Moreover, since in Spain different layers of government invest in transportation infrastructures, it may not be appropriate to analyze central government's investment decisions without taking into account the investment made by subnational governments ${ }^{13}$. Therefore, it might be appropriate to account for the possibility of substitutability/complementarity in the production function of the infrastructures provided by different layers of government. This interrelation may ultimately make central government's investment depend on investment made by the other layers ${ }^{14}$.

This section proposes a simple transformation in order to be able to estimate the model with investment made by the central government as the dependent variable and with the investment made by subnational governments as an additional explanatory variable. First, after some operations on the permanent inventory equation we are able to write ${ }^{15}$ :

$$
\Delta \ln C_{i t} \cong\left(I_{i t} / C_{i t-1}\right)-\delta
$$

Second, we assume that when computing the increase of the capital stock, the central government considers both the increase due to its own investment and a proportion $\theta$ of the invest-

\footnotetext{
${ }^{12}$ As we will explain in the next section, the available data base does not provide information on capital stocks by level of government (Fundación BBVA, 1998). The capital stock provided is total capital stock but information about gross investment is presented by level of government.

${ }^{13}$ For example, both the central government and the regional and local governments have some responsibilities regarding road construction. Although the nature of those roads differs among layers (i.e., the central government is the only one having responsibilities in inter-regional motorways), they can be hardly considered as independent as production inputs.

${ }^{14}$ See Aronsson et al. (2000) for an analysis of interactions in the spending decisions made by different layers of government in Sweden. In that case, the source of expenditure interactions is the relationship among goods in the utility function, not among factors in the production function. This work is also related to a recent but growing literature that analyzes tax interactions among levels of govern-ment (e.g., Besley and Rosen, 1998 and Goodspeed, 2001).

${ }^{15}$ By rearranging the permanent inventory equation and after taking logs we find that $\Delta \ln C_{i t}=\ln \left(1+I_{i t}\right.$ $/ C_{i t-1}-\delta$ ); the left hand side can be approximated by $I_{i t} / C_{i t-1}-\delta$ when this expression approaches zero.
} 
ment made by the other levels of government. This parameter measures the degree of substitutability between investments made by different levels of government. If $\theta=1$, the central government is indifferent about which level of government is ultimately responsible for the increase in the capital stock. If $\theta=0$, investment projects of the different levels of government are completely independent. Of course, in the current period, the central government does not know the investment that will be made by the other layers. We now assume that the central government expects that investment made by other layers will be roughly the same than the year before. Taking this into account then we can express (11) as:

$$
\Delta \ln C_{i t} \cong I_{i t}^{c} / C_{i t-1}+\theta .\left(I_{i t-1}^{S} / C_{i t-2}\right)
$$

Where $c$ is central and $s$ subnational (i.e., regional + local). In the case of $\Delta \ln C_{i t-1}$, the central government already knows the amount invested the year before and therefore we can write:

$$
\Delta \ln C_{i t-1} \cong I_{i t-1}^{c} / C_{i t-2}+\theta .\left(I_{i t-1}^{S} / C_{i t-2}\right)
$$

Substituting expressions (12) and (13) in (10) and ordering terms, we obtain the following equation explaining investment made by the central government $\left(I^{c}{ }_{i t} / C_{i t-1}\right)$ :

$$
\begin{aligned}
I_{i t}^{c} / C_{i t-1}= & (1-\rho) .\left(I_{i t-1}^{c} / C_{i t-2}\right)-\rho \cdot \theta \cdot\left(I_{i t-1}^{S} / C_{i t-2}\right)+\rho \cdot \phi \cdot \Delta \ln Y_{i t} \\
& +\rho .(1-\phi) \cdot \Delta \ln N_{i t}+\rho \cdot \Delta \ln S_{i t}^{x}+\rho \cdot \Delta \ln E_{i t}^{c}+\rho \cdot \Delta \ln \Psi_{t i}+f_{t}+\eta_{i} \cdot f_{t}+\Delta \varepsilon_{i t}
\end{aligned}
$$

This expression states that investment made by the central government in a region in a given year depends on the investment it made the year before (due to adjustment costs), but also on the investment made the year before by other layers of government. The significance of investment made by other layers will ultimately provide a check of the need to include this variable in the equation.

Equation (14) constitutes the focus of the empirical analysis. However, this equation will also be estimated with investment data corresponding to the aggregate of all government levels. In this case the specification will differ a bit from expression (14). The first difference is that, in this case, there would be no need investment made by other layers of government as an explanatory variable. The second difference is that the parameter $\lambda_{t}$ (appearing as a part of $B_{i t}$ ) can not be considered constant across regions. The reason is that regionally or locally financed investment depends on the budget constrain of subnational governments, which is not identical across regions. Some variables should be included in the equation to account for 
these differences. Third, political factors specific of regional and local governments $\left(\Psi^{\prime}{ }_{i t}\right)$ should be included in the equation. With these changes, the equation explaining investment made by all layers of government $\left(I_{i t} / C_{i t-1}\right)$ can be expressed as:

$$
\begin{aligned}
& I_{i t} / C_{i t-1}=(1-\rho) \cdot\left(I_{i t-1} / C_{i t-2}\right)+\rho \cdot \phi \cdot \Delta \ln Y_{i t}+\rho \cdot(1-\phi) \cdot \Delta \ln N_{i t} \\
& \quad+\rho \cdot \Delta \ln S_{i t}^{x}+\rho \cdot \Delta \ln E_{i t}^{c}+\rho \cdot \Delta \ln \lambda_{t}+\rho \cdot \Delta \ln \Psi_{i t}+\rho \cdot \Delta \ln \Psi_{i t}^{\prime}+f_{t}+\eta_{i} \cdot f_{t}+\Delta \varepsilon_{i t}
\end{aligned}
$$

\subsection{Sample, variables and data sources}

Equations (14) and (15) will be estimated separately with data on transportation infrastructure investment made by the central government and by all levels of government in each of the 50 Spanish departments (NUTS3) during the period 1987-96. The source of data on capital stock and infrastructure investment by government level and region is: Fundación BBVA (1998), "The capital stock in Spain and its territorial distribution". This data base has been previously used in many empirical analysis estimating production functions and growth equations and its accuracy is widely accepted ${ }^{16}$.

Two different equations will be estimated, one for total transportation investment (including roads, railroads, ports and airports) and another one for roads, that are the main category covering more than half of all transportation investments. We decide not to include separate regressions for other categories because, first, each of them represents a low share of the total and, second, because its analysis is affected by some problems. For example, investments in nodal infrastructures (e.g., ports and airports) only occur in the regions having these facilities. Investments in these categories also use to come in big individual projects, meaning that a higher volatility is observed in the series of regional investment (e.g., construction of a high speed railroad may cause an spike in investment in one period that would not repeat in the following years). However, we feel that a broader category may not be equally affected by this problem.

We choose NUTS3 regions as a unit of analysis (instead of NUTS2) for two reasons. First, because of a pure econometric concern about the the number of observations available $(\mathrm{N}=50$ instead of N=17 in the NUTS2 case). Second, because the calculation of some of the variables included in the model only has sense in the NUTS3 case. For example, as will be later

\footnotetext{
${ }^{16}$ See e.g,., Mas et al. (1996), and De la Fuente and Vives (1995) for analysis using this data set; Mas et al.(2000) provides a description of the method of calculation of capital stocks.
} 
explained, some political variables are included to pick up the electoral cloud of the regions. But since electoral jurisdictions for general elections in Spain are NUTS3 regions it may be inappropriate to tie the electoral incentives to broader areas. There are also various reasons that justify the focus on the period 1987-96. The first one is that while data on regional allocation of investment and capital stocks are available in Spain for a broader period (see Fundación BBVA, 1998), the information about investments made by the different layers is not available until the eighties. The second one is that actual infrastructure responsibilities of regional governments (Comunidades Autónomas) were not completed until the middle of the eighties ${ }^{17}$.Therefore, it is important to exclude this first period from the analysis. Third, because the information needed to quantify some of the variables (i.e., those coming form the production function, as vehicles and utilisation) is not available for a longer period.

Explanatory variables can be classified in three groups: economic variables, political variables and control variables picking up the financial resources of regional governments. Table 1 summarizes the definitions of the variables and data sources. Among economic variables, we have included both output growth $\left(\Delta \ln Y_{i t}\right)$ and population growht $\left(\Delta \ln N_{i t}\right)$, and variables coming directly form the specificaction of the production function $\left(\Delta \ln S^{x}{ }_{i t}\right.$ and $\left.\Delta \ln E_{i t}^{c}\right)$. Output growth is real regional GDP growth at market prices.

[Table 1 about here]

The share of vehicles in output $\left(S^{x}{ }_{i t}\right)$ has been proxied by a log-linear relationship among number of trucks and GDP, of the form: $S_{i t}^{x}=\left(\operatorname{Trucks}_{i t} / Y_{i t}\right)^{\delta}$. Trucks are the actual number of trucks and other industrial vehicles (e.g., vans) in each region. This is the best way to deal with this problem, given the unavailability of information on vehicle capital stocks ${ }^{18}$. The elasticity of infrastructure services to infrastructure stock $\left(\Delta \ln E_{i t}^{c}\right)$ has been proxied by variables quantifying the growth in the number of users. That is, we assume that the effect of an increase in the stock (e.g., reduction of congestion) is higher the higher is the level of users of this stock ${ }^{19}$. The variables used to compute the increase in the number of users have been

\footnotetext{
${ }^{17}$ In addition to this, the regional financing system was highly provisional until second half of that decade. The equation explaining investment made by all levels of governments will include some variables measuring the financial position of regional governments.

${ }^{18}$ Of course, it would have been more appropriate to follow the procedure used in Fernald (1999); that is, to compute the annual consumption of vehicle services as the product of the vehicle stock and a user cost of vehicle capital (accounting for depreciation and fiscal treatment).

${ }^{19}$ Many empirical papers use a constant-elasticy especification of the level of services provided by infrastructures: $Z_{i t}=C_{i t} / U_{i t}{ }^{\alpha}$. Note, however, that in this case $E_{i t}^{c}=1$ in all the regions and this term will
} 
selected to represent different kinds of transportation infrastructures. In the case of roads the variable used is the increase in the number of $\mathrm{km}$ per year travelled by vehicles in each region $\left(\Delta \ln K m_{i t}\right)$. In the case of airports and railroads, we use growth in passengers/year $\left(\Delta \ln A i r_{i t}\right.$ and $\Delta \ln$ Rail $\left._{i t}\right)^{20}$, and in the case of ports growth in tons of goods transported per year $\left(\Delta \ln\right.$ Port $\left._{i t}\right)$.

Variables included in the $\Psi_{i t}$ term pick up political factors considered by the central government when allocating funds to the regions. Some recent political economy papers may help in selecting these variables (Levitt and Snyder, 1995, Johansson, 1999, Cadot et al., 1999, and Case, 2001). In these papers the main determinants of regional redistribution are, for example, the potential electoral gains in the region, the desire to benefit party constituentcies, or the presence of active interest groups in some regions. Here we will focus on the first two factors: potential electoral gains and partisan effects. We consider that potential electoral profitability in a region depends on the probability of gaining or loosing representatives therein $^{21}$. To account for this effect we include in the equation a variable $\left(\operatorname{Margin}_{i t}\right)$ that measures the proportion of votes that the incumbent party would have needed to gain or loose one additional representative in the region in the last election held. This variable has been computed for the elections of 1982, 1989 and 1993 through a very simple algorithm that reproduces the electoral rule system d'Hondt. First, we calculate the proportion of votes needed for the socialist government (the incumbent in the three contests) to gain and lose a representative in the upper chamber (Congreso). Second, the variable $\left(\right.$ Margin $\left._{i t}\right)$ is computed as the minimum of these two values for each region ${ }^{22}$. The expected sign for this variable is negative: the marginal benefit of investing in a region is higher the lower is the number of votes needed to gain or loose a representative. In fact, the inclusion of this variable may be considered an extension of the analysis of Case (2001), which quantifies the margin of victory as the distance between the vote proportion in the last election and $50 \%$. Of course, this

disappear form our specification. To allow $E_{i t}^{c}$ depend on the number of users one has to posit a more general functional form, as for example the translog function used by Boarnet (2001).

${ }^{20}$ In this last case the data is available only for the period 1991-96. Because of this the equations in which this variable appears have been estimated only with data belonging to this sample.

${ }^{21}$ Electoral profitability also depends on the size of the region (given the lack of proprotionality of the electoral system). To account for this effect we included a new variable: the ratio between population and number of representatives in each region. However, this variable displayed too low temporal variation to be used in an equation in differences.

${ }^{22}$ The calculation assumes that all the votes lost or gained by the incumbent are gained or lost by the second party in number of votes in the region. We repeated the calculation with different vote shifting assumptions (e.g., distribution according to previous vote share). However, the results of the variable $\operatorname{Margin}_{i t}$ in the investment equation are not qualitatively altered. 
procedure may not be entirely appropriate in our case, since Spain is not a pure bi-partisan system and the rela-tionship between votes and representatives depends on the operation of the d'Hondt system.

The second political factor considered is the will to provide benefits for own party constituencies. We take this factor into account by including a variable that measures the absolute electoral support received by the incumbent party in the region: the proportion of votes obtained by the incumbent in the last election $\left(\operatorname{Vgov}_{i t} / \operatorname{Vtot}_{i t}\right)$. We expect this variable to have a positive sign; that is, the central government invests more in the regions were it receives more electoral support. We include also other political variables that may account either for the first or the second factor, or for both. The first variable accounts for the similarity of the partisan orientation of the central and the regional governments; as in all the period analyzed the central government was controlled by the socialist party, the variable used is a dummy equal to one if the regional government is on the left wing of the political spectrum $\left(\operatorname{dleft}(R)_{i t}\right)$. We also include a dummy equal to one if the main party in the regional government gives support to the central government during the period 1993-96 $\left(\operatorname{dmin}(C)_{i t}\right)^{23}$. We expect a positive sign for both variables; that is, we expect that the central government invests more in regions controlled by socialists, and during the period 1993-96, also in regions controlled by parties whose support is needed to sustain the executive.

In the equations explaining investment activity by all levels of government (15), an additional set of political variables $\left(\Psi_{i t}{ }^{\prime}\right)$ are included. These are a dummy equal to one if regional elections are held during the year in the region $\left(\right.$ deyear $\left._{i t}\right)$, and a dumy equal to one if the regional government does not have a majority of representatives in the regional parliament $\left(d \min (R)_{i t}\right)$. We expect a higher level of investment in electoral years but the sign of $d \min (R)_{i t}$ is uncertain. Some papers suggest that governments with a low degree of internal cohesion will spend more due to the highest difficulty to stop the redistributive pressures they find (see, e.g., Roubini and Sachs, 1989, and Alt and Lowry, 1995). However, this effect needs not to be the same in all expenditure categories. A possible story may be, for example, the cut in investment projects due, precisely, to the success of other redistributive programs.

\footnotetext{
${ }^{23}$ In these years the socialists were in minority in the central government and received the support of the nationalist parties of the regions of Catalonia, Basque Country and Canary Islands.
} 
Finally, equation (15) also includes some variables accounting for the budget constraint of each regional government $\left(\lambda_{i t}\right)$. These variables are: unconditional revenues $\left(\operatorname{Rev}_{i t}\right)$, capital transfers $\left(\mathrm{Cap}_{i t}\right)$, and the debt level $\left(D e b t_{i t}\right)$. All these variables are computed for the NUTS2 region that is the level of aggregation corresponding to regional governments in Spain. Therefore, it value is the same for all the NUTS3 regions included in the same regional government. The sign expected is positive in the case of the resource variables and negative in the case of debt.

\subsection{Econometric issues}

Before estimating equations (14) and (15) two main econometric problems should be addressed: (i) the possible endogeneity of some explanatory variables, and (ii) the estimation of a dynamic panel data model.

The endogeneity problem affects mainly to the output growth variable $\left(\Delta \ln Y_{i t}\right)$. In fact, the production function states that $\Delta \ln Y_{i t}$ is a function of $\Delta \ln C_{i t}$, meaning that reverse causality may be a problem. This problem may affect also the variables included in the $\Delta \ln S_{i \text { it }}^{x}$ and $\Delta \ln E^{c}{ }_{i t}$ terms. Although we have not proposed any explanatory model for these variables, it is easy to tell some story to explain how infrastructure improvement in a region biases the economic structure of the region increasing the share of vehicle-intensive sector. A similar explanation could be invoked to argue that an infrastructure improvement may in fact increase the level of traffic and, therefore, create more congestion in the long run ${ }^{24}$. The solution we have adopted to solve this problem consists of introducing all these variables in the estimated equation with a lag. That is, we consider that all of them are predetermined. This way to proceed is consistent with the information set that the central government has when deciding how much to invest in a region. We feel thus it is appropriate to assume that this information set only includes past values of the variables. The only variables that are introduced simultaneously are the political ones.

Regarding the second problem, note that equations in first differences (14) and (15) include the lagged value of the dependent variable $\left(I_{i t-1} / C_{i t-1}\right)$. In addition to that, if the error term in the levels equation $\left(\varepsilon_{i t}\right)$ was uncorrelated, then error term in the differenced equation will show negative first order autocorrelation $\left(\varepsilon_{i t}-\varepsilon_{i t-1}\right)$. If this is the case, the lagged dependent

\footnotetext{
${ }^{24}$ Although, as recently has been shown by Prakash et al. (2001), this relationship is not supported by the data, at least in the UK.
} 
variable will be correlated with the error term and OLS estimators will be biased if the number of years in the panel is small (Nickel, 1981, and Arellano and Bond, 1991). The solution to this problem consist of estimating equations (14) and (15) by the Generalizad Method of Moments (GMM), using lagged values of variables in levels as instruments (Arellano and Bond, 1991) ${ }^{25}$. In our case, we will use as instuments for $I_{i t-1} / C_{i t-1}$ three lags of infrastructure stock $\left(\ln C_{t-2}, \ln C_{t-3}\right.$ and $\left.\ln C_{t-4}\right)$. These instruments will be the same for all the years in the sample.This procedure will not suppose loosing any of the cross-sections, because we have information for the instruments in years preceding those of used in the analysis.

The assumption of no serial correlation in $\varepsilon_{i t}$ is crucial to guarantee the consistency of the GMM estimator. For this reason, we will provide two tests of serial correlation. We expect to find first order serial correlation in the residuals but not second order serial correlation. We also include a Sargan test of overidentifying restrictions to check for the validity of the set of instruments (Arellano y Bond, 1991). This test is distributed under the null of instrument validity as a $\chi^{2}$ with degrees of freedom equal to the number of overidentifying restrictions.

\section{Results}

The results obtained in the estimation of equation (14) are presented in Table 2. The first three columns correspond to the investment made by the central government in transportation infrastructure, while the other three correspond to the investment in roads. Table 3 shows the results obtained when repeating the exercise for the investment made by all levels of government (equation 15). The explanatory capacity of the model is high in both cases, with an adjusted R2 around $60 \%$. The bottom of both tables shows the results of a battery of specification statistics. In all the cases, the time effects are significant but the hypothesis that are the same both for regions receiving and not receiving earmarked investment funds can not be rejected. Also the serial correlation tests shows that there is first order serial correlation in the residuals of the differenced model but no second order correlation. This fact gives us some confidence in the appropriateness of the instrument set, that is confirmed by the results of the Sargan test.

\footnotetext{
${ }^{25}$ In presence of heteroscedasticy and residual serial correlation it is more efficient to use the two-step GMM procedure. However, as Arellano and Bond (1991) note, this estimator is rather inefficient. Following the recommendation of these authors, we present the results of the first-step GMM estimator.
} 
The order of presentation of the results in Tables 2 and 3 is the same. Columns (a) and (d) show the results of a specification that only includes as variables: lagged investment made by the central government and lagged investment made by other layers of government (only in Table 2), output growth, population growth and the ratio of trucks to output. Columns (b) and (e) show the results obtained when adding the utilization variables. Finally, the specification in columns (c) and (f) also includes the political variables and the other control variables.

Regarding the results obtained, we must highlight the following conclusions. First, investment made both by the central government and by all levels of government adjust slowly towards the optimal capital stock. The value of the adjustment coefficient $\rho$ moves between 0.24 and 0.27 , depending on the equation. Given that the economic variables enter in the equation with a lag, this means that investment needs from 4 to 5 years to fully adjust in response to an exogenous regional shock. Second, the coefficient estimated for the investment made by other layers of government in Table 2 is negative and statistically significant in all the cases. This result is consistent with the hypothesis of substitutability among the investment made by different layers of government. The $\theta$ parameter ranges from $-0.16(\approx-0.042 /(1-0.733))$ in the case of Transportation to -0.27 in the case of roads. This fact suggests that if a subnational government invests 4 additional euro in roads, the central government will reduce its road investment in the same region by 1 euro.

\section{[Table 2 and 3 about here]}

Third, the results also show that infrastructure investment is sensitive to output growth and the coefficients are statistically significant at a conventional level. This happens irrespective of the level of government involved (i.e.,central vs. all levels) and of the category analysed (i.e., transportation or roads). In the central government case the coefficient is equal to 0.15 in both cases (1.c and 1.f), implying a value for $\phi$ around 0.5 (see Table 4 estimated values of the structural parameters). According to this result, the central government does not follow exclusively an efficiency criteria when allocating infrastructure investment across regions (recall that this requires $\phi=1$ ). In the case of investment made by all levels of government the output coefficient is 0.18 for transportation and 0.20 for roads, meaning that the parameter $\phi$ is 0.73 and 0.77 , respectively. Therefore, it seems that the infrastructure investment policy conducted by the overall Spanish public sector is more efficiency-oriented than that of the central government. In fact, a simple calculation suggests that $\phi$ for the subnational govern- 
ments would be very close to one ${ }^{26}$. These results are not surprising; after all, subnational governments only worry about growth promotion in its own jurisdiction, while the central government cares both about national output growth and about its regional distribution.

Fourth, the impact of population growth is positive and statistically significant (although only at the $90 \%$ in most equations). In all the cases the population coefficient is lower than the output coefficient. In addition to that, it is not possible to reject the null hypothesis that the population coefficient $(1-\phi)$ is equal to one minus the output coefficient $(\phi)$. Therefore, the main results are consistent with the predictions of the theoretical model.

[Table 4 about here]

Five, the growth in the output-share of transportation services $\left(S^{x}\right)$, proxied by $\Delta \ln \left(T r u c k s_{t-}\right.$ $\left.{ }_{1} / Y_{t-1}\right)$, also has a positive and highly statistically significant impact on investment. In the case of transportation investment the long term effect (Table 4) is 0.517 for the central government and 0.640 for all levels. In the case of roads the coefficients are higher, of 0.756 and 0.840 , respectively. Therefore, although vehicle-intensity may be a better proxy for trans-portation service intensity in the case of roads, it has also a considerable effect in the case of other transportation infrastructures. The utilization variables appear to have a lower impact on investment. The growth in vehicle-km $\left(\Delta \ln K m_{t-1}\right)$ has a positive impact in all the equations, although the coefficient is significant only at the $90 \%$ level and not in all the cases. In the case of investment made by the central government, the long term coefficient of this variable (Table 3) is 0.048 for transportation and 0.087 for roads. So, the effect is higher in the case of roads. This also occurs in the equations explaining investment made by all levels of government. Growing utilization of railroads, ports and airports also have a positive impact on transportation investment, although only the last variable is statistically significant.

Six, the political variables appear, in general, with the expected sign. Let's first analyze its effects on the investment decisions made by the central government. The sign of the dummy $\operatorname{dleft}(R)_{i t}$ is always positive bur never significant at conventional levels. Thus, we can not conclude that the central government invest more in ideologically akin regions. The support of nationalist parties to the central government also has a positive impact on infrastructure investment, although only significant at the $90 \%$ in the case of roads. The sign of the variable

\footnotetext{
${ }^{26}$ To do this simple exercise assume that the $\phi$ of all levels is just a weighted average of those of central and subnational governments, and use as a weight the share of the central government in investment in theses categories (that was nearly $40 \%$ in 2001, Ministerio de Fomento).
} 
that measures the vote-share of the incumbent party $\left(\operatorname{Vgov}_{i t} / V t o t_{i t}\right)$ is positive in the two equation but only statistically significant in the case of roads. The impact of the variable $\operatorname{Margin}_{i t}$ is negative and significant in the two equations. These results suggest that the objectives of incumbent parties (at least in the case of roads) are mixed: they invest where it is more profitable in terms of votes but also where partisan support is higher. Although the parameter values are not really high, they can not be neglected. For example, the parameter of the road equation means that a reduction of one point in the margin of victory in a region (say from $2 \%$ to $1 \%$ of votes) would force an increase of 0.135 in the growth rate of road infrastructures. Since the average sample value for Margin $_{i t}$ is $3.66 \%$, this means that for the average region in the sample, having this margin (instead of a value of zero) causes a $0.49 \%$ drop in road investment made by the central government (the mean sample value for this variable being $6.02 \%)^{27}$.

In the case of investment made by all levels of government the only political variable that remains statistically significant is also $\operatorname{Margin}_{i t}$. The coefficient in the transportation equation is quite similar than in the central government's case, although only significant at the $90 \%$ level. However this variable remains highly significant at the $99 \%$ in the road equation. This result suggest that investment made by regional government is also used as a tool in general election contests. After all, the parties that compete in the general elections also compete in regional contests. And if it is worth to invest in a contested department, this will be true both for the party in the central government and for the party in the regional government (that may or may not be the same $)^{28}$.

Seven, the variables accounting for the budget constraint of regional governments appear with the expected sign in equation explaining investment made by all the layers of government: unconditional revenues $\left(\ln \Delta R e v_{i t}\right)$ and capital funds $\left(\ln \Delta C a p_{i t}\right)$ have a positive effect while debt has a negative effect $\left(\ln \Delta D e b t_{i t}\right)$. The coefficient of capital funds is not significant at conventional levels, although it is of similar magnitude than the other ones.

\footnotetext{
${ }^{27} \mathrm{We}$ also tried another specification allowing different responses in regions where the margin of victory is positive and negative. The results were similar in both cases.

${ }^{28}$ One may be tempted to suggest that this result is due to a higher amount of transfers from the central government to the regional or local governments in these pivotal regions. This is not very plausible, since the amount of resources available for regional governments has been already controlled in the equation.
} 


\section{Conclusions}

This paper has analyzed the main determinants of transportation infrastructure investment allocation across regions. The investment equation is derived from a simple theoretical model that accounts simultaneously for an efficiency-equity trade-off, political factors and specific regional infrastructures needs. This equation has been estimated with data on transportation investment and capital stock in 50 Spanish NUTS3 regions. We have analyzed separately the investment made by the central government and the investment made by all levels of government. The results suggest that the central government balances equity and efficiency in the allocation of regional government but that investment by all the levels of government is more inclined towards efficiency. Technical aspects influencing the output effects of transportation infrastructure provision (i.e., output-vehicle share, level of utilization) also appear to be relevant. However, government's motives are not confined to the efficiencyequity trade-off: political considerations play also a role in the regional investment allocation process. The central government invests more in the regions where the risk of gaining or loosing a representative is higher but also in regions (at least in the case of roads) where partisan support is higher. The financing system of regional governments also seems to play a role in the investment made by all levels of government.

We consider that the result obtained may be useful both in terms of valued added to the literature on economic effects of infrastructures and in analyzing economic policy options. For example, both the theoretical model and the results suggest that infrastructure capital responds positively to output growth. This will ultimately mean that infrastructure capital should be considered as endogenous in production function estimation. Although this concern has been raised by many authors (Duffy-Deno y Eberts, 1991, Tatom, 1991 y 1993, Cadot et al., 1999, Fernald, 1999, and Röller and Waverman, 2000) it is not always clear at all how to proceed to solve the econometric problem. Our results will help in the selection of instruments to be used in the estimation of the production function. A different paper, Castells et al. (2001), uses the same data set to regress growth in total factor productivity on growth in transportation infrastructure. The elasticitiy obtained when infrastructure growth is instru- 
mented with some of the political variables identified here (e.g., $\operatorname{Margin}_{i t}, \operatorname{Vgov}_{i} /$ Vtot $_{i t}$ ) is twice that the one obtained by OLS estimation ${ }^{29}$.

Another possible application of the results of the paper consists of combining the coefficient estimates (mainly that of the efficiency-equity trade off, $\phi$ ) with an estimate of the outputelasticity of infrastructure capital to compute the efficiency loss of a given allocation rule. This result may help in order to appropriately judge the desirability of maintaining current redistributive regional policies. The model also allows us to calculate the possible welfare loss due to unequal treatment arising from political discrimination. A calculation like this would help to evaluate the need to maintain the actual ability of the central government to change regional investment allocation at his will or, to the contrary, the appropriateness of a reform based on objective rules. This paper is only a modest step towards the understanding of this problems and further and deeper analysis would be needed in the future. Possible improvements and extensions may include, for example, the consideration of private transportation infrastructures, the proper treatment of nodal infrastructures, or the estimation of the effects of european regional funds on infras-tructure investment made by the different layers of government.

\section{References}

Alt, J. and Lowry, R.C., 1995: "Divided government and budget deficits: evidence from the states", American Political Science Review, 88, 811-828.

Anderson, T.W. and Hsiao, C., 1981: Estimation of dynamic models with error components. Journal of the American Statistical Association, 76, 598-606.

Arellano, M. and Bond, S., 1991: Some tests of specification for panel data: Monte Carlo evidence and an application to employment equations. Review of Economic Studies, 58, 277-297.

Aronsson, Th.; Lundberg, J. and Wikström, M., 2000: The impact of regional public expenditures on the local decision to spend, Regional Science and Urban Economics, 30(2), 185-202.

Berhman, J.R. and Craig, S.G., 1987: The distribution of public services: an exploration of local government preferences. American Economic Review, 77, 315-332.

\footnotetext{
${ }^{29}$ The OLS elasticity is in the range of $0.10-0.15$, depending on the specification, while the same value in the Instrumental Variables case ranges from 0.25 to 0.30 . Previous empirical analysis estimating production functions in Spain ( Mas et al., 1996) obtained values of this elasticity similar to our OLS results, while the Instrumental Variables results are near those originally obtained by Aschauer (1989).
} 
Berhman, J.R. and Sah, R.K., 1984: What role does equity play in the international distribution of aid. En Syrquin, M. (ed.): Economic structure and performance. Academic Press, New York, 295-315.

Boarnet, M. G., 2001: "Infrastructure services and the productivity of public capital: the case of streets and highways", National Tax Journal, 67, 39-57.

Boix, C., 1995: Partidos políticos, crecimiento e igualdad: estrategias económicas conservadoras y socialdemócratas en la economía mundial, Alianza Ed., Madrid.

Bosch, N. and Espasa, M., 1999: ¿Con qué criterios invierte el Sector Público central?, en A. Castells and N. Bosch (eds.): Desequilibrios territoriales en España y en Europa, Ariel Ed., Madrid.

Cadot, O.; Röller, L. and Stephan, A., 1999: A political economy model of infrastructure allocation: an empirical assessment. Discussion Paper 2336, CEPR.

Case, A., 2001: Election goals and income redistribution: recent evidence from Albania. European Economic Review, 45, 405-423.

Castells, A. and Solé, A., 2000: Cuantificación de las necesidades de gasto de las Comunidades Autónomas: Metodología y aplicación práctica. Instituto de Estudios Fiscales. Madrid.

Castells, A.; Montolio, D. and Solé, A., 2001: Las necesidades de gasto de las Comunidades Autónomas en infraestructuras. Instituto de Estudios Fiscales. Madrid.

Craig, S.G. and Heikkila, E.J., 1989: Urban safety in Vancouver: allocation and production of a congestible good. Canadian Journal of Economics, 22, 867-884.

Dahlberg, M. and Johansson, E., 1999: On the vote purchasing behaviour of incumbent governments. Mimeo. Department of Economics, Uppsala University.

De la Fuente, A., 1999: Algunas reflexiones sobre el papel redistributivo de la inversión pública. En Castells, A. y Bosch, N. (eds.): Desequilibrios territoriales en España y en Europa. Ariel, Barcelona, 137-149.

De la Fuente, A., 2001: Infraestructuras y política regional, Estudios sobre la Economía Española, 112, FEDEA.

Vives, X. and De la Fuente, A., 1995: Infrastructure and Education as Instruments of Regional Policy: Evidence from Spain. Economic Policy, 20, 11-54.

Dixit, A. and Londregan, J., 1998: Ideology, tactics, and efficiency in redistributive politics. Quarterly Journal of Economics, 113, 497-529.

Duffy-Deno, K.T. and Eberts, R.W., 1991: Public infrastructure and regional economic development: a simultaneous equation approach. Journal of Urban Economics, 30, 329343.

Edwards, J.H.Y., 1990: "Congestion function specification and the 'publicness' of local public goods", Journal of Urban Economics, 27, 80-96.

Fernald, J.G., 1999: "Roads to prosperity? Assessing the link between public capital and productivity, American Economic Review, 89(3), 619-638.

Fisher and Turnovsky, 1998: Public investment, congestion and private capital accumulation, Economic Journal, 399-414. 
Fundación BBVA (1998): El stock de capital publico en España y su distribución territorial.

Glomm, G. and Ravikumar, B., 1994: Public investment in infrastructure in a simple growth model, Journal of Economic Dynamics and Control, 18, 607-625.

Gramlich, E.M., 1994: Infraestructure investment: A review essay. Journal of Economic Literature, 32, 1176-1196.

Holtz-Eakin, D. and Rosen, H., 1989: The rationality of municipal construction spending: evidence from New Jersey. Regional Science and Urban Economics, 19, 517-36.

Holtz-Eakin, D. and Rosen, H., 1993: Municipal construction spending: an empirical examination. Economics and Politics, 5, 61-84.

Holtz-Eakin, D.; Newey, W. and Rosen, H., 1988: Estimating vector autoregressions with panel data. Econometrica, 56, 1371-1396.

Johansson, E., 1999: Intergovernmental grants as a tactical instrument: some empirical evidence from Swedish municipalities. Mimeo. Department of Economics, Uppsala University.

Lago, S., 2001: La dinámica del gasto de capital de las CCAA: un análisis de sus determinantes, Hacienda Pública Española, 157/2, 65-82.

Levitt, S.D. and Snyder, J.M., 1995: Political parties and the distribution of federal outlays. American Journal of Political Science, 39, 958-980.

Mas, M.; Maudos, J.; Pérez, F. and Uriel, E., 1996: Infrastructures and productivity in the Spanish Regions. Regional Studies, 30, 641-649.

Mas, M., Pérez, F. and Uriel, E., 2000: Estimation of the Stock of Capital in Spain, The Review of Income and Wealth, 46 (1), 103-116.

Ministerio de Fomento, 2001: Evolución de la inversión pública 1990-98, www.mfom.es.

Röller, L. and Waverman, L., 2000: Telecomunications infrastructure and economic development: a simultaneous approach. Discussion Paper 2399, CEPR.

Roubini, N. and Sachs, J., 1989: "Political and economic determinants of budget deficits in industrial democracies", European Economic Review, 33, 903-938.

Prakash, A.B.; Oliver, E.H. and Balcombe, K., 2001: Does building new roads create extra traffic? Some new evidence, Applied Economics, 33, 1579-1585.

Petchey, J.; MacDonald, G.; Koshy, P. and Shapiro, P., 2000: Capital equalization and the Australian states. Economic Record, 76, 32-44.

Tatom, J.A., 1991: Public capital and private sector performance. Federal Reserve Bank of Sant Louis Economic Review, 73, 3-15.

Tatom, J.A., 1993: Is an infrastructure crisis lowering the nations productivity? Federal Reserve Bank of Sant Louis Economic Review, 75, 27-42. 
Table 1

Variable definitions and data sources

\begin{tabular}{|c|c|c|}
\hline Variable & Definition & Sources \\
\hline$I_{t}^{c} / C_{t-1}$ & $\begin{array}{l}\text { Investment by central government a year } \\
\text { divided by capital stock the year before }\end{array}$ & Fundación BBVA (1998) \\
\hline$I_{t} / C_{t-1}$ & $\begin{array}{c}\text { Investment by all levels of government a } \\
\text { year divided by capital stock the year } \\
\text { before }\end{array}$ & Fundación BBVA (1998) \\
\hline$I_{t-1}^{S} / C_{t-2}$ & $\begin{array}{c}\text { Investment by subnationall governments } \\
\text { the year before divided by capital stock } \\
\text { two years before }\end{array}$ & Fundación BBVA (1998) \\
\hline$\Delta \ln Y_{t-1}$ & Output growth rate & $\begin{array}{l}\text { Regional Accounts, Instituto Nacional } \\
\text { de Estadística (INE) }\end{array}$ \\
\hline$\Delta \ln N_{t-1}$ & Population growth rate & $\begin{array}{l}\text { Population Statistics } \\
\text { Instituto Nacional de Estadística (INE) }\end{array}$ \\
\hline$\Delta \ln \left(\right.$ Trucks $\left._{t-1} / Y_{t-1}\right)$ & Growth rate of the ratio trucks on output & Ministerio de Fomento \\
\hline$\Delta \ln K m_{t-1}$ & Growth rate of vehicles-km per year & Ministerio de Fomento \\
\hline$\Delta \ln$ Rail $_{t-1}$ & Growth rate in rail passengers per year & RENFE \\
\hline$\Delta \ln$ Port $_{t-1}$ & Growth rate in tons transported per year & Ministerio de Fomento \\
\hline$\Delta \ln A i r_{t-1}$ & Growth rate in air passengers per year & Ministerio de Fomento \\
\hline $\operatorname{dleft}(R)_{t}$ & $\begin{array}{l}\text { Dummy equal to one if the regional } \\
\text { government is on the left-wing spectrum } \\
\text { of the political arena }\end{array}$ & Anuario EL PaíS \\
\hline $\operatorname{dmin}(C)_{t}$ & $\begin{array}{l}\text { Dummy equal to one if the main party in } \\
\text { the regional government gives support to } \\
\text { the central government that is in } \\
\text { minority }\end{array}$ & Anuario EL PaíS \\
\hline $\operatorname{Vgov}_{t} /$ Vtot $_{t}$ & $\begin{array}{l}\text { Incumbent's share of votes in the last } \\
\text { election }\end{array}$ & Anuario EL PaíS \\
\hline $\operatorname{Margin}_{t}$ & $\begin{array}{l}\% \text { of votes needed for the incumbent to } \\
\text { gain/loost a representative in the last } \\
\text { election }\end{array}$ & Anuario EL PaíS and own calculations \\
\hline $\operatorname{dmin}(R)_{t}$ & $\begin{array}{l}\text { Dummy equal to one if the regional } \\
\text { government is in minority in the regional } \\
\text { parliament }\end{array}$ & Anuario EL PaíS \\
\hline deyear $(R)_{t}$ & $\begin{array}{l}\text { Dummy equal to one if regional } \\
\text { elections are held in that region and year }\end{array}$ & Anuario EL PaíS \\
\hline$\Delta \ln R e v_{t-1}$ & $\begin{array}{l}\text { Growth of general revenues of the } \\
\text { regional government (Own taxes and } \\
\text { charges }+ \text { Ceded taxes }+ \text { General } \\
\text { transfers from the central gov. - General } \\
\text { transfers to the central gov.) }\end{array}$ & $\begin{array}{l}\text { Liquidación de los Presupuestos de las } \\
\text { CCAA and Informe sobre la } \\
\text { financiación de las Comunidades } \\
\text { Autónomas (Ministerio de Economía) }\end{array}$ \\
\hline$\Delta \ln \operatorname{Cap}_{t}$ & $\begin{array}{l}\text { Growth of capital revenues of the } \\
\text { regional government (European funds }+ \\
\text { Spanish regional policy }+ \text { joint tasks }+ \\
\text { other specific grants) }\end{array}$ & $\begin{array}{l}\text { Liquidación de los Presupuestos de las } \\
\text { CCAA and Informe sobre la } \\
\text { financiación de las Comunidades } \\
\text { Autónomas (Ministerio de Economía) }\end{array}$ \\
\hline$\Delta \ln D e b t_{t-1}$ & $\begin{array}{c}\text { Growth in net debt of the regional } \\
\text { government }\end{array}$ & Anuario Estadístico (Banco de España) \\
\hline
\end{tabular}


Table 2

Determinants of infrastructure investment, Central government, 1987-96.

GMM estimation. Dependent variable: $I_{t}^{c} / C_{t-1} . N \times T=50 \times 10=500$.

\begin{tabular}{|c|c|c|c|c|c|c|}
\hline & \multicolumn{3}{|c|}{ Transportation } & \multicolumn{3}{|c|}{ Roads } \\
\hline & (1.a) & (1.b) & $(1 . c)$ & (1.d) & (1.e) & (1.f) \\
\hline$I_{t-1}^{c} / C_{t-2}$ & $\begin{array}{c}0,728 \\
(10,463)^{* * *}\end{array}$ & $\begin{array}{c}0,720 \\
(9,965)^{* * * *}\end{array}$ & $\begin{array}{c}0,733 \\
(9,129)^{* * *}\end{array}$ & $\begin{array}{c}0,750 \\
(25,480)^{* * *}\end{array}$ & $\begin{array}{c}0,749 \\
(25,483)^{* * *}\end{array}$ & $\begin{array}{c}0,725 \\
(23,717)^{* * *}\end{array}$ \\
\hline$I_{t-1}^{s} / C_{t-2}$ & $\begin{array}{c}-0,055 \\
(-2,354)^{* *}\end{array}$ & $(-2,841)^{* * * *}$ & $\begin{array}{c}-0,042 \\
(-2,977)^{* * *}\end{array}$ & $\begin{array}{c}-0,069 \\
(-1,471)\end{array}$ & $\begin{array}{c}-0,066 \\
(-1,415)\end{array}$ & $\begin{array}{c}-0,075 \\
(-1,975)^{* *}\end{array}$ \\
\hline$\Delta \ln Y_{t-1}$ & $\begin{array}{c}0,252 \\
(5,662)^{* * *}\end{array}$ & $\begin{array}{c}0,201 \\
(3,844)^{* * *}\end{array}$ & $\begin{array}{c}0,150 \\
(2,489)^{* * *}\end{array}$ & $\begin{array}{c}0,279 \\
(4,069)^{* * *}\end{array}$ & $\begin{array}{c}0,251 \\
(3,487)^{* * *}\end{array}$ & $\begin{array}{c}0,152 \\
(2,640)^{* * *}\end{array}$ \\
\hline$\Delta \ln N_{t-1}$ & $\begin{array}{c}0,162 \\
(1,188)\end{array}$ & $\begin{array}{c}0,101 \\
(1,108)\end{array}$ & $\begin{array}{c}0,079 \\
(1,851)^{*}\end{array}$ & $\begin{array}{c}0,173 \\
(1,119)\end{array}$ & $\begin{array}{c}0,175 \\
(1,138)\end{array}$ & $\begin{array}{c}0,129 \\
(2,035)^{*}\end{array}$ \\
\hline$\Delta \ln \left(\right.$ Trucks $\left._{t-1} / Y_{t-1}\right)$ & $\begin{array}{c}0,212 \\
(5,141)^{* * *}\end{array}$ & $\begin{array}{c}0,184 \\
(4,054)^{* * *}\end{array}$ & $\begin{array}{c}0,138 \\
(2,085)^{* *}\end{array}$ & $\begin{array}{c}0,224 \\
(3,357)^{* * *}\end{array}$ & $\begin{array}{c}0,204 \\
(2,980)^{* * * *}\end{array}$ & $\begin{array}{c}0,158 \\
(2,148)^{* *}\end{array}$ \\
\hline$\Delta \ln K m_{t-1}$ &.---- & $\begin{array}{c}0,014 \\
(1,622)\end{array}$ & $\begin{array}{c}0,013 \\
(1,725)^{*}\end{array}$ &.---- & $\begin{array}{c}0,024 \\
(1,560)\end{array}$ & $\begin{array}{c}0,024 \\
(1,736)^{*}\end{array}$ \\
\hline$\Delta \ln$ Rail $_{t-1}$ &.---- & $\begin{array}{c}0,067 \\
(1,540)\end{array}$ &.---- &.---- &.---- &.---- \\
\hline$\Delta \ln$ Port $_{t-1}$ &.---- & $\begin{array}{c}0,002 \\
(0,438)\end{array}$ & $\begin{array}{c}0,002 \\
(0,472)\end{array}$ &.---- &.---- &.---- \\
\hline$\Delta \ln A i r_{t-1}$ &.---- & $\begin{array}{c}0,016 \\
(1,985)^{* * *}\end{array}$ & $\begin{array}{c}0,012 \\
(1,689)^{*}\end{array}$ &.---- &.---- &.---- \\
\hline $\operatorname{dleft}(R)_{t}$ &.---- &.---- & $\begin{array}{c}0,006 \\
(1,620)\end{array}$ &.---- & $--\cdot--$ & $\begin{array}{c}0,001 \\
(1,565)\end{array}$ \\
\hline$d \min (C)_{t}$ &.---- &.---- & $\begin{array}{c}0,002 \\
(1,520)\end{array}$ &.---- &.---- & $\begin{array}{c}0,003 \\
(1,770)^{*}\end{array}$ \\
\hline $\operatorname{Vgov}_{t} /$ tot $_{t}$ &.---- & $--\cdot--$ & $\begin{array}{c}0,006 \\
(0,789)\end{array}$ &.---- &.---- & $\begin{array}{c}0,056 \\
(2,246)^{* *}\end{array}$ \\
\hline $\operatorname{Margin}_{t}$ &.--- &.---- & $\begin{array}{c}-0,108 \\
(-2,115)^{* *}\end{array}$ &.--- & $--\cdot--$ & $\begin{array}{c}-0,135 \\
(-2,155)^{* *}\end{array}$ \\
\hline$R^{2}$ & 0,594 & 0,598 & 0,612 & 0,577 & 0,590 & 0,615 \\
\hline$F\left(f_{t} v s . f\right)$ & $2,060^{* *}$ & $2,056^{* *}$ & $2,441^{* *}$ & $2,520^{* * *}$ & $2,438^{* * *}$ & $2,342^{* * *}$ \\
\hline$F\left(\left(\eta_{i} \times f_{t} v s . f_{t}\right)\right.$ & 0,145 & 0,104 & 0,621 & 0,423 & 0,510 & 0,885 \\
\hline Serial corr. $\left(1^{\text {st }}\right.$ order $)$ & $-2,845^{* * *}$ & $-2,758^{* * *}$ & $-2,550^{* * *}$ & $-2,002^{* * * *}$ & $-2,984^{* * *}$ & $-2,995^{* * *}$ \\
\hline Serial corr. $\left(2^{\text {nd }}\right.$ order $)$ & $-0,987$ & $-0,967$ & $-0,990$ & $-0,145$ & $-0,252$ & $-0,341$ \\
\hline Sargan & $26,114^{* * *}$ & $24,223^{* *}$ & $28,463^{* * * *}$ & $19,019^{* * *}$ & $18,001^{* *}$ & $22,014^{* * * *}$ \\
\hline
\end{tabular}

Notes: (1) $t$ statistics in brackets; $* * *=$ coefficient significant at the $99 \%$, level $* *=$ coefficient significant at the $95 \%$ level, $*=$ coefficient significant at the $90 \%$ level, (2) time effects included, (3) Instruments used: $\ln C_{t-2}, \ln C_{t-3}$ and $\ln C_{t-4}$. 
Table 3

Determinants of infrastructure investment, All levels of government, 1987-96.

GMM estimation. Dependent variable: $I_{t} / C_{t-1} . N \times T=50 \times 10=500$.

\begin{tabular}{|c|c|c|c|c|c|c|}
\hline & \multicolumn{3}{|c|}{ Transportation } & \multicolumn{3}{|c|}{ Roads } \\
\hline & (2.a) & (2.b) & (2.c) & (2.a) & (2.b) & (2.c) \\
\hline$I_{t-1} / C_{t-2}$ & $\begin{array}{c}0,771 \\
(12,921)^{* * *}\end{array}$ & $\begin{array}{c}0,760 \\
(12,507)^{* * *}\end{array}$ & $\begin{array}{c}0,761 \\
(11,215)^{* * *}\end{array}$ & $\begin{array}{c}0,785 \\
(11,020)^{* * *}\end{array}$ & $\begin{array}{c}0,787 \\
(11,084)^{* * *}\end{array}$ & $\begin{array}{c}0,737 \\
(10,041)^{* * *}\end{array}$ \\
\hline$\Delta \ln Y_{t-1}$ & $\begin{array}{c}0,288 \\
(5,350)^{* * * *}\end{array}$ & $\begin{array}{c}0,214 \\
(4,051)^{* * * *}\end{array}$ & $\begin{array}{c}0,181 \\
(2,133)^{* *}\end{array}$ & $\begin{array}{c}0,502 \\
(7,026)^{* * * *}\end{array}$ & $\begin{array}{c}0,495 \\
(6,926)^{* * * *}\end{array}$ & $\begin{array}{c}0,204 \\
(2,134)^{* *}\end{array}$ \\
\hline$\Delta \ln N_{t-1}$ & $\begin{array}{c}0,175 \\
(1,758)^{*}\end{array}$ & $\begin{array}{c}0,075 \\
(1,920)^{*}\end{array}$ & $\begin{array}{c}0,072 \\
(1,851)^{*}\end{array}$ & $\begin{array}{c}0,287 \\
(1,765)^{*}\end{array}$ & $\begin{array}{c}0,299 \\
(1,727)^{*}\end{array}$ & $\begin{array}{c}0,121 \\
(1,877)^{*}\end{array}$ \\
\hline$\Delta \ln \left(\right.$ Trucks $\left._{t-1} / Y_{t-1}\right)$ & $\begin{array}{c}0,225 \\
(4,629)^{* * *}\end{array}$ & $\begin{array}{c}0,188 \\
(3,978)^{* * *}\end{array}$ & $\begin{array}{c}0,153 \\
(1,968)^{* * *}\end{array}$ & $\begin{array}{c}0,442 \\
(6,703)^{* * *}\end{array}$ & $\begin{array}{c}0,442 \\
(6,718)^{* * *}\end{array}$ & $\begin{array}{c}0,221 \\
(2,778)^{* * * *}\end{array}$ \\
\hline$\Delta \ln K m_{t-1}$ &.---- & $\begin{array}{c}0,016 \\
(1,814)^{*}\end{array}$ & $\begin{array}{c}0,016 \\
(1,898)^{*}\end{array}$ & --.-- & $\begin{array}{c}0,026 \\
(1,479)\end{array}$ & $\begin{array}{c}0,030 \\
(1,768)^{*}\end{array}$ \\
\hline$\Delta \ln$ Rail $_{t-1}$ &.---- & $\begin{array}{c}0.080 \\
(1,117)\end{array}$ &.---- &.---- & --.-- &.---- \\
\hline$\Delta \ln$ Port $_{t-1}$ &.---- & $\begin{array}{c}0,002 \\
(0,221)\end{array}$ & $\begin{array}{c}0,001 \\
(0,304)\end{array}$ &.---- &.---- & --.-- \\
\hline$\Delta \ln A i r_{t-1}$ &.---- & $\begin{array}{c}0,026 \\
(2,812)^{* * *}\end{array}$ & $\begin{array}{c}0,021 \\
(2,219)^{* *}\end{array}$ &.---- &.---- &.---- \\
\hline$\Delta \ln R e v_{t-1}$ &.---- & --.-- & $\begin{array}{c}0,002 \\
(2,396)^{* *}\end{array}$ &.---- & $\begin{array}{ll}--.-- \\
\end{array}$ & $\begin{array}{c}0,003 \\
(2,305)^{\text {** }}\end{array}$ \\
\hline$\Delta \ln C a p_{t}$ &.---- &.---- & $\begin{array}{c}0,001 \\
(1,550)\end{array}$ &.---- & --.-- & $\begin{array}{c}0,003 \\
(1,600)\end{array}$ \\
\hline$\Delta \ln D e b t_{t-1}$ & $--\cdot--$ &.---- & $\begin{array}{c}-0,005 \\
(-2,967)^{* * *}\end{array}$ &.---- & $--\cdot--$ & ${ }^{-0,002}(-2,344)^{* * *}$ \\
\hline $\operatorname{dleft}(R)_{t}$ & $--\cdot--$ & $--\cdot--$ & $\begin{array}{c}0,005 \\
(1,266)\end{array}$ & $--\cdot--$ & $--\cdot--$ & $\begin{array}{c}0,016 \\
(1,300)\end{array}$ \\
\hline$d \min (C)_{t}$ &.---- &.---- & $\begin{array}{c}0,001 \\
(0,345)\end{array}$ &.---- &.---- & $\begin{array}{c}-0,001 \\
(-0,278)\end{array}$ \\
\hline$d \min (R)_{t}$ &.---- &.---- & $\begin{array}{c}-0,002 \\
(-0,579)\end{array}$ &.---- & --.-- & $\begin{array}{c}0,001 \\
(1,123)\end{array}$ \\
\hline deyear $(R)_{t}$ &.---- &.---- & $\begin{array}{c}0,002 \\
(0,548)\end{array}$ &.---- &.---- & $\begin{array}{c}0,001 \\
(0,231)\end{array}$ \\
\hline $\operatorname{Vgov}_{t} /$ Vtot $_{t}$ & $--\cdot--$ &.---- & $\begin{array}{c}0,004 \\
(1,465)\end{array}$ &.---- &.---- & $\begin{array}{c}0,008 \\
(1,306)\end{array}$ \\
\hline Margin $_{t}$ &.---- &.---- & $\begin{array}{c}-0,103 \\
(-1,683)^{*}\end{array}$ &.---- &.---- & $\begin{array}{c}-0,216 \\
(-2,748)^{* * *}\end{array}$ \\
\hline$R^{2}$ & 0,593 & 0,642 & 0,667 & 0,524 & 0,526 & 0,573 \\
\hline$F\left(f_{t} v s . f\right)$ & $3,940^{* * *}$ & $3,710^{* * * *}$ & $3,589^{* * * *}$ & $2,885^{* *}$ & $2,927^{* *}$ & $3,270^{* *}$ \\
\hline$F\left(\left(\eta_{i} \times f_{t} v s . f_{t}\right)\right.$ & 0,214 & 0,337 & 0,961 & 0,741 & 0,601 & 0,636 \\
\hline Serial corr. $\left(1^{\text {st }}\right.$ order $)$ & $-2,110^{* * *}$ & $-2,021^{* * *}$ & $-2,004^{* * *}$ & $-2,911^{* * *}$ & $-2,925^{* * *}$ & $-2,966^{* * *}$ \\
\hline Serial corr. $\left(2^{\text {nd }}\right.$ order $)$ & $-0,554$ & $-0,652$ & $-0,492$ & $-0,784$ & $-0,654$ & $-0,581$ \\
\hline Sargan & $17,114^{* * *}$ & $16,559^{* * *}$ & $18,240^{* * *}$ & $20,001^{* * *}$ & $20,0112^{* *}$ & $17,004^{* * *}$ \\
\hline
\end{tabular}

Notes: See Table 1 
Table 4

Structural parameters of key variables

\begin{tabular}{|c|c|c|}
\hline & Central gov. & All levels \\
\hline & \multicolumn{2}{|c|}{ Transportation } \\
\hline $\ln Y$ & $\begin{array}{c}0.502 \\
(2.103)^{* * * *}\end{array}$ & $\begin{array}{c}0.731 \\
(2.003)^{* *}\end{array}$ \\
\hline $\ln N$ & $\begin{array}{c}0.295 \\
(1.790)^{*}\end{array}$ & $\begin{array}{c}0.289 \\
(1.688)^{*}\end{array}$ \\
\hline $\ln ($ Trucks/Y) & $\begin{array}{c}0.517 \\
(2.003)^{* *}\end{array}$ & $\begin{array}{c}0.628 \\
(1.852)^{*}\end{array}$ \\
\hline $\ln K m$ & $\begin{array}{c}0.048 \\
(1.621)\end{array}$ & $\begin{array}{c}0.058 \\
(1.720)^{*}\end{array}$ \\
\hline \multirow[t]{2}{*}{$\ln$ Air } & $\begin{array}{c}0.012 \\
(1.667)^{*}\end{array}$ & $\begin{array}{c}0.020 \\
(2.102)^{* * *}\end{array}$ \\
\hline & \multicolumn{2}{|c|}{ Roads } \\
\hline $\ln Y$ & $\begin{array}{c}0,552 \\
(2,350)^{* * *}\end{array}$ & $\begin{array}{c}0,775 \\
(2,211)^{* *}\end{array}$ \\
\hline $\ln N$ & $\begin{array}{c}0,469 \\
(1,855)^{*}\end{array}$ & $\begin{array}{c}0,380 \\
(1,986)^{\text {** }}\end{array}$ \\
\hline $\ln ($ Trucks $/ Y)$ & $\begin{array}{c}0,574 \\
(2,054)^{* *}\end{array}$ & $\begin{array}{c}0,603 \\
(1,977)^{\text {*** }}\end{array}$ \\
\hline $\ln K m$ & $\begin{array}{c}0,087 \\
(1,668)^{*}\end{array}$ & $\begin{array}{c}0,075 \\
(1,691)^{*}\end{array}$ \\
\hline
\end{tabular}

Notes: (1) $z$ statistics in brackets; $* * *=$ coefficient significant at the $99 \%$, level $* *=$ coefficient significant at the $95 \%$ level, $*=$ coefficient significant at the $90 \%$ level, (2) Only variables that appear to be statistically significant in some cases are included (3) Political variables are not considered. 